\title{
DEVELOPMENT OF STUDENT ECOPRENEURSHIP POTENTIAL THROUGH LEARNING BASED PROJECTS MODEL IN SOCIAL STUDIES LEARNING (Classroom Action Research in Class VII-A MTs Ar-Rohmah Bandung)
}

\author{
Sri Rahayu * \\ ayu_srirahayu92@yahoo.co.id \\ Social Science Education Studies Program
}

\author{
Nana Supriatna \\ Yeni Kurniawati,
}

\begin{abstract}
This research related to the development of the potential of ecopreneurship students through project-based learning. The purposeof this research is caused by unrest demonstrated by students either in the process of learning which is very flat as well as assessment of the student's active role in the learning or suggested the practice as a form of character development. Researchers take a character-based entrepreneurial environment because the research location close to traditional and modern market. Problem formulated which examined is, related how the design, implementation, as well as the obstacles that occur in this research. The research method used is the classroom action research method using designs from Lewin according to Elliot. The design research of Lewin according to Elliot in each cycle begins with planning, action, observation, and reflection. Data collection techniques used are observation, field note, and documentation study. The instrument used is the observation sheet and rubric. Based on the research that has been done shows that project-based learning model can be an alternative model which could develop the potential of ecopreneurship grade VII-A MTS. Ar-Rohmah Bandung. This can be seen from the increase in the indicators of research after two cycles with a total of eight actions. The increase occurred on the indicators create, explore, creative, innovative, and confident. The results of this research can be an alternative to developing the social studies study that allows students to explore his creativity by doing a practice jump, so that learning becomes more meaningful for teachers as a student or as a characterforming the subject of the creation of the character.
\end{abstract}

Keywords: project-based learning, the potential ecoprenership.

\section{INTRODUCTION}

In this globalization era, it is important that the characters building and skills that teachers must be given to the students. It is intended that students can become a person capable of facing the challenges of globalization in the future. Globalization in question here is more directed to the aspect of job opportunities that allegedly can be mastered by technology. In this current reality, even college graduates of higher education must have a special skill to support employment opportunities needed by the public or the society. Therefore, skill-oriented education begins to be nurtured in learning for students from an early age.
Skills training for students here is a combination of character education as a foundation of movement and contextual aspects to hone students' accuracy in facing the challenges of globalization. Character is important for the achievement of the purpose of life, can even be a boost in the choice to determine the best in life. Therefore, the development of character is one of the great efforts in shaping the students on the choice of the best life goals.

Today many students graduated from junior high or high school who only capitalize the academic output alone without having any special skills. This may impact on the existing unemployment rate resulting from an imbalance between recent graduates who are still productive but minimal skills and the needs of workers for the public are those with special skills. The Government has made efforts to solve the problems related to the level of unemployment through entrepreneurship to the community. Should teachers in any level of education, especially on the subject matter of social studies contribute in government efforts to reduce the unemployment rate through the provision of skills tucked in the middle of classroom learning.

It can be concluded that Indonesia is currently intensively sharpening the new generation in the skills aspect both in the field of education and through training. It became one of the supporting researchers to choose the aspect of entrepreneurship in conducting research. Other reinforcing factors, the researchers chose this aspect because there are several values of character based on the nation's culture that can be used as an indicator of research in terms of entrepreneurship.

\section{METHODS}

The study was conducted in Mts. Ar-Rahmah Bandung located at Sukajadi Street No.140, Bandung City, West Java 40161. Researcher Collaborator or teacher partner in this research is Social Studies teacher at class VII-A, Ms. Ineu Gusniyartini, S.Sos. The subject in this research is the students of class VII-A Odd Semester 2016/2017 Mts ArRahmah Bandung, with the number of 32 students consisting of 16 male students and 16 female students. According to Dewey in Thornton (1994: 5) defines classroom action research as reflective thinking in an ever-active, resilient 
educational experience, and always considers all forms of knowledge to be taught based on belief in the reasons that support and think about the conclusions and their consequences that knowledge will bring the students.

In this Classroom Action Research the researcher uses Lewis model revision according to Elliot model (Wiraatmadja, 2012: 64) which explains that in each cycle consists of several steps. In each cycle there are several actions, namely three to five actions that are manifested in the form of teaching and learning activities. The general scheme of Elliot's model in Classroom Action Research is as follows :

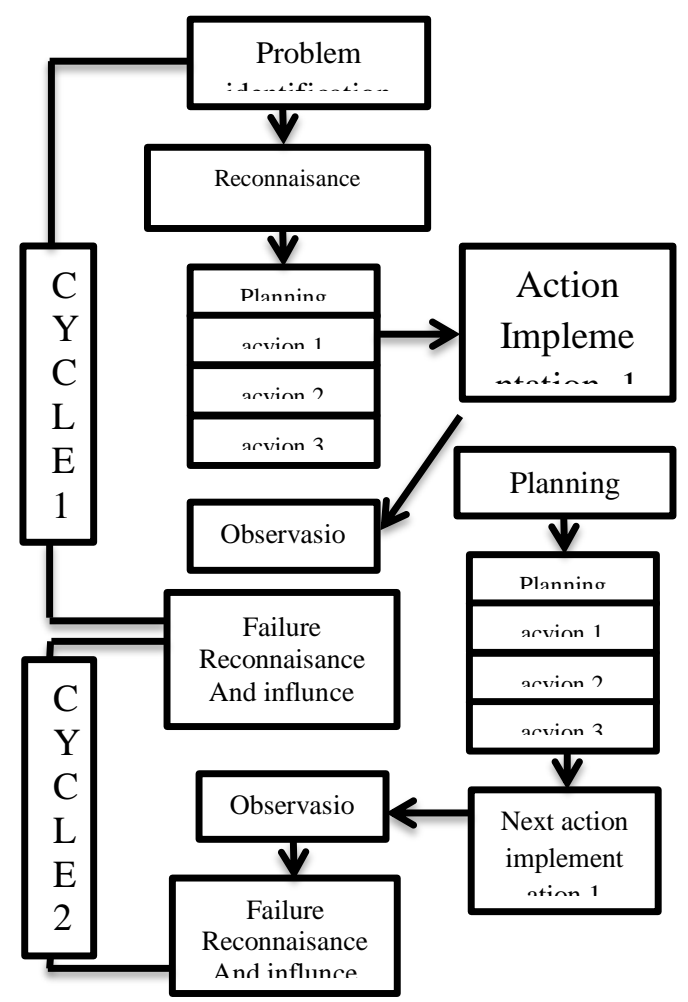

The research instruments used are observation guides, field notes, and documentation. So the technique of data collection is observation, and documentation study. The data validation using the Hopkins model as cited by Wiriatmaja, 2005, p. 168171) including member check, triangulation, saturation, audit trail and expert opinion.

\section{RESULTS AND DISCUSSION}

The results of this study refers to the problems formulation such as design planning, implementation, and the constraints and solutions of Social Studies learning to develop the potential of student ecopreneurship using project-based learning model in class VII-A MTs. Ar-Rohmah Bandung.

The first step, the researcher and the partner's teacher compose the theme, sub theme and sub-theme in accordance with the learning objectives to be achieved by the researcher. This is certainly based on the findings of problems that occur in the field and therefore researchers with teacher partners plan learning that can solve the problem. The selected theme is the theme of "Demand, Quotes, Market Prices, and Markets in Economic Activities" with subtitles "Economic Activity, Demand, Bid, and Price Balance in Economic Activities" in cycle I and sub theme "Market, Types of Markets , The Role of Science and Technology and the Role of Entrepreneurship in Economic Activities "in cycle II. Furthermore, the researcher and the partner teacher discussed in order to make the Learning Implementation Plan to be implemented in every action. Researchers and partner teachers develop potential indicators of student ecopreneurship in each learning plan that is expected to be achieved from each action.

The researcher and the partner teacher determine the type of project to be carried out in the research in each cycle and determine the student's activities at each stage of project implementation. Indicators of ten ecopreneurship points are outlined as indicators in the observation format of potential development of the student's ecopreneurship. In addition, the researchers also formulate the observation format of the implementation of project-based learning and assessment criteria.

In cycle I, plans have been developed by researchers and partner teachers to develop the potential of ecopreneurship through the implementation of value added projects for used goods. Researchers provide theoretical information about project-based learning to be implemented and explain each stage. Students in groups carry out each stage of value adding projects for used goods in cycle I. Students can find and utilize used items and even garbage around. Together in a group of students using their creativity to create a work in the form of valuable products for used goods. Furthermore, students present the products they produce in front of the class to train their confidence which then conducted product auctions to further develop students' entrepreneurial potential. Groups can also provide constructive feedback, suggestions, and criticisms to other groups. The potential development of the student's ecopreneurship will be measured along with the assessment of the implementation of project-based learning.

In cycle II, the researcher and the partner teacher agreed to correct the shortcomings that occurred in the cycle I there are students confusion about the stages of the project-based learning model, students still do not highlight the potential of ecopreneurship. In addition, researchers also still difficult to set the time so that it exceeds the time of the lesson. Obstacles that occur in the cycle of I fixed in cycle II is in terms of reexplain the project stage and assessment criteria, motivate students to leih seriously in implementing the project and mobilize all the ability and rearrange the allocation of learning time. Students will be asked to make products based on valuable goods. Students in groups will be asked to be able to price the products they produce and determine the target market of the product. In the second cycle both the potential of student ecopreneurship and assessment of the implementation of project-based learning students have increased significantly.

Changes in planning conducted by researchers in cycle I is one of the stages in the process of research activities in the 
next cycle of cycle II. Where the change is the result of reflection or revision of cycle I activities conducted by researchers and teacher partners to correct errors that occur. In general, project-based learning process can develop student's ecopreneurial potential in social studies learning. Through this project's learning, students create two products made of

\section{Student Potencial Ecopreneurship in Every Cycles}

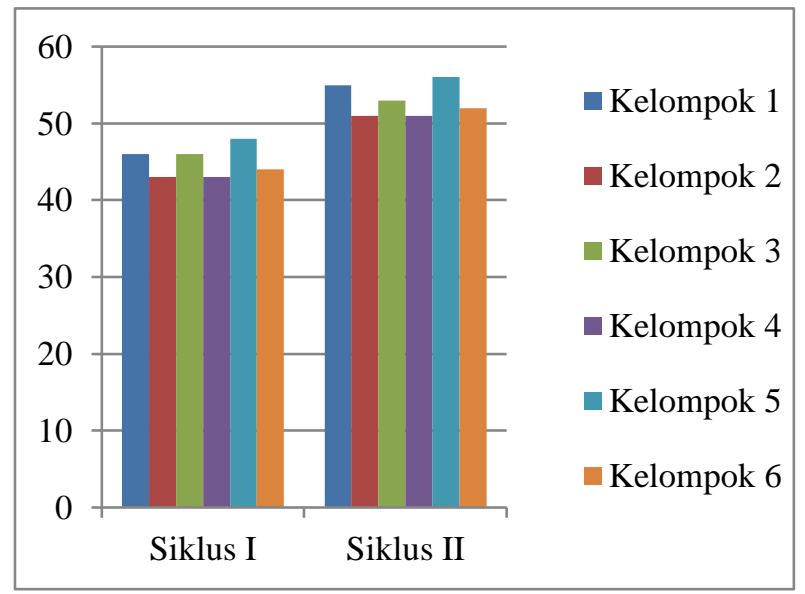

Based on the results of the above data, it can be indicated that the potential ecopreneurship that researchers develop through this project-based learning model has increased the average from cycle I to cycle II. Group 1 experienced an increase in the number of values from 46 in the first cycle to 55 in cycle II. Group 2 experienced an increase in the number of values from 43 in the first cycle to 51 in cycle II. Group 3 experienced an increase in the number of values from 46 in cycle I to 53 in cycle II. Group 4 experienced an increase in the number of values from 43 in the first cycle to 51 in cycle II. Group 5 experienced an increase in the number of values from 48 in cycle I to 56 in cycle II. Group 6 experienced an increase in the number of values from 44 in the first cycle to 52 in cycle II. Of the 6 project groups, group 1 shows the greatest increase for the potential ecopreneurship shown in this project-based learning among other groups. Each group experienced an increase, indicating that students can enhance the potential development of ecopreneurship within themselves through project-based learning.

In the first cycle of the average development of the potential of ecopreneurship owned by students is equal to $71.4 \%$ or it can be said that the potential of ecopreneurship of students is quite developed through this project-based learning. Then in cycle II, the potential of ecopreneurship owned by students rose to $84.1 \%$ or can be said good, it is certainly a good development in terms of potential

well. Students demonstrate performance improvement during project implementation and are able to demonstrate attitudes and behaviors that reflect the potential development of ecopreneurship.

Third, there is an increased assessment of the implementation of project-based learning in grades VII-A MTs. Ar-Rohmah Bandung from cycle I and II that is equal to $11,5 \%$. In cycle I the percentage of project-based learning secondhand goods, which with the products that students have created can support or support the development of the potential of the student's ecopreneurship. To know how to increase the potential, then below is presented diagram assessing potential of student's ecopreneurship in each cycle as follows:

development of ecopreneurship students. The potential of this student's ecopreneurship rises in line with the implementation of project-based learning.

After the researchers observed, see the condition in the first cycle students already have a pretty good ecopreneurship potential, but still needs to be improved again. Based on the findings in cycle I, the researcher and the partner teacher discussed to find a way out so that students can improve and develop their own ecopreneurial potential. Thus in cycle 2 , the potential of ecopreneurship reflected in student behavior increased by $12.3 \%$ from the previous cycle. Students have begun to demonstrate the potential of their own ecopreneurship and reflect it in their attitudes and behaviors when undertaking project-based learning.

\section{D. Conclusion}

The conclusion of the research entitled "Development of Student's Ecopreneurship Potential Trough a Project Based Learning Model in Class VII-A MTs. Ar-Rohmah Bandung is:

First, the development planning of students' ecopreneurship potential using a project-based learning model in Social studies learning seen student starting from one to two cycles is classified under the "good" category. The planning activities undertaken are determining the Competency Standards and Basic Competencies, subject matter, making the Lesson Plans, making speaking cards and observation sheets.

Second, the implementation of the potential development of the student's ecopreneurship using a project-based learning model in the Social Studies lesson from one to four cycles is classified as "good". This can be seen from the acquisition of percentage ability of researchers in developing the potential of ecopreneurship in each cycle. In cycle I, there are various constraints such as students still confused about the use of project-based learning model because this is the first assignment of the student project, the allocation of time exceeding the hours of learning, the student still dare not use his own words in answer and presentation, and researcher it is still difficult to condition the class. However, in cycle II thanks to the discussion of researchers and partner teachers, the constraints encountered in the Idapat cycle are resolved implementation showed students score $70.6 \%$. while in the second cycle showed an increase to $82.1 \%$. Data of observation result of student's ecopreneurship potential development showed increase percentage. In cycle $\mathrm{I}$, the potential of student ecokreneurism that arose during projectbased learning was $71.4 \%$. In the second cycle, the increase was quite good by $12.3 \%$ to $84.1 \%$. it shows that after being given 6 actions, the use of project-based learning model can be 
one alternative learning model to develop the potential of student's ecopreneurship.

\section{ACKNOWLEDGEMENT}

Thanks to the department of Social Studies Education for publishing this journal article.

\section{REFERENCE}

Arikunto, S., Suhardjono., \& Supardi. (2015). Penelitian Tindakan Kelas. Jakarta: Bumi Aksara.

Djamarah, S. (2010). Guru dan Anak Didik dalam Interaksi Edukatif. Jakarta: Rineka Cipta

Goleman, D. (2010). Ecological Intelligence mengungkap rahasia dibalik produk-produk yang kita beli. Jakarta: PT

Gramedia Pustaka Utama

Iskandar. (2009). Penelitian Tindakan Kelas. Jakarta: Gaung Persada Press.

Joyce, B. dan Weil, M. (1980). Models of Teaching. New York: Prentice Hall

Sani, R.A. (2015). Pembelajaran Saintifik untuk Implementasi Kurikulum 2013. Jakarta: Bumi Aksara
Sumaatmadja, N. (1979). Metodologi Pengajaran Ilmu Pengetahuan Sosial. Bandung: Alumni 1984

Soemanto, W. (2006). Pendidikan Berwirausaha. Jakarta: Bumi Aksara

Supriatna, Nana. (2016). Ecopedagogy membangun

kecerdasan Ekologis siswa dalam pembelajaran IPS.

Bandung:Rosda

Wiriaatmaja, R. (2010). Metode Penelitian Tindakan Kelas. Bandung: Rosdakarya.

Jurnal:

Anih, E. (2015). Ecopreneurship Education Berbasis Prakarya dalam Kurikulum 2013. Jurnal Pendidikan Guru Sekolah Dasar. 1 (1). Subang: STKIP Suban

Untari, D.T. (2011). Ecopreneurship Dalam Konsep

Pembangunan yang Berkelanjutan. Jurnal Pendidikan. Jakarta: Universitas Indraprasta PGRI

Dyah, Y. (2016). Model Pembelajaran Berbasis Proyek pada Pembelajaran Fisika Disma. Jurnal pendidikan. Jember: Universitas Jember 